\section{Induction and Mentoring Perspectives of Incoming Pre-service Faculty of Education Students}

\section{Raymond T. Chodzinski, Joanne Graham and Kris Kirkwood}

$\mathrm{R}$ esearch to determine beginning teacher expectations and perceptions about pre service programmes and induction practices and how those can be translated into meaningful experiences during the formulation stages of a beginning teacher's career is important. What is reported here comprises a general and partial summary of the results of the first phase of a two-part study in progress that addresses this concern.

The perceptions and expressed needs of more than 400 pre-service students as they relate to expectations about induction and mentorship experiences during and subsequent to the pre-service year at Brock Faculty of Education were surveyed. The hypothesis and context of the study is that incoming pre-service students believe that induction and mentorship experiences are highly important, but that they are extensively exterior to the Faculty of Education program rather than embedded in it. Moreover, preservice students believe that it is the responsibility of the school board partner to provide induction and mentorship rather than faculties of education.

\section{Overview}

The key to educational improvement lies in the preparation of new teachers and the ongoing professional development of practicing teachers (Cobb, Darling-Hammond \& Murangi, 1995; Chodzinski, 1994, Manley-Casimir 2000). Reform to professional standards and expectations of teachers and licensing and certification procedures have been established by professional bodies such as The Ontario College of Teachers, the National Board for Professional Teaching Standards, the National Council for Accreditation of Teacher Education (NCATE), and the Interstate New Teacher Assessment \& Support Consortium (INTASC). Darling-Hammond (1993, 1999) argues that revised standards are reshaping what beginners know from their own schooling experience and what is expected from them as teachers. Moreover it is suggested that there exists a critical need to understand the potential for partnerships between pre-service settings, induction contexts and later professional development activities in meeting the demands of reform.

Kagan's (1992) review of research on professional growth of beginning teachers concludes that what teachers believe about teaching and learning strongly influences what they do in their classrooms. Clark \& Peterson, (1986) suggest that the success of a teacher education program lies in its' ability to facilitate the cognitive and behavioural changes necessary to produce effective teachers for the $21^{\text {st }}$ century. Stombus and Chodzinski (1998) argue it is im- perative that those in charge of preparing teachers for the future must provide ongoing assistance to reduce problems known to be common to beginning teachers and that are known to be antecedents for career dissatisfaction. Knowing what teachers need and expect from faculties and employers will help to provide induction experiences and will build on the foundation to create pathways for ongoing professional growth. Cole (1994), Cowieson (1995) and Matier (2002) echo the professional voice that school administrators have a responsibility to work with all education stakeholders and partners to ensure the smooth transition of beginning teachers from the first stage of training and certification onward through career growth toward professional maturity.

Revised expectations require changes in attitudes and beliefs. Chodzinski (1994, 1999) makes the point that studies need to address the perceived needs and expectations of beginning teachers enrolled in teacher education programs because they are the front line change agents and the messengers of the message. Beginning teachers strive to be proficient in instructional strategies and building relationships with students and they express a desire to improve and acquire new skills as they advance from novice teacher status to veteran teacher professional. Clifford (1991) recommended that faculties of education, teacher employers, and professional associations must work together to provide life long learning opportunities for teachers as they advance through their career journey.

"Induction is a vital part of the preparation and development of a professional teacher" p. 2.

Chodzinski (2002) suggests that veteran teachers and new re- 
tirees hold the key to enhancing opportunities for induction and mentorship through creative alliances with faculties of education and school board sponsored induction experiences.

\section{Method}

This research investigated the stated beliefs and perceptions of pre-service candidates to items listed as part of five survey questions about the pre-service program and subsequent induction expectations. More than 400 students responded to the pre-survey and post-survey. They were asked to indicate on the basis of a Likert-type scale, ranging from strongly disagree to strongly agree, which program and professional items listed would in their perception help best prepare them for success as a teacher during the pre-service and induction periods.

The results to each question were analyzed in terms of means and frequencies and were subjected to chi-square analyzes and t-tests to determine significant differences. Reliability coefficients obtained a Cronbach's alpha of .91 across the 54 items.

\section{Findings}

Results show that overall; pre-service students who participated in this study clearly define the importance of items on the survey as meaningful within three categories. They are professional coaching and advice by veteran teachers, curriculum and instructional knowledge and skills and other professional responsibilities and service. Responses remained essentially the same as far as grouping for both pre- and post-test response sets before analysis of specific differences. Independent t-tests of pre and post survey responses revealed that means for females were con- sistently higher than for the males for all significant items.

Female participants in this study tended to place greater emphasis on the importance of many of the teacher preparation issues than males. They expect to have more contact from extended support systems such as the principal and vice-principal, and finally they perceive greater benefits from formal induction programs with regard to improving collegiality, promoting professional growth and especially providing emotional support.

With respect to the first grouping, professional coaching, beginning teachers report they believe (based on ranking) that experienced teachers, peer beginning teachers, principals and vice principals, practice teaching and using the curricula in practice are the best sources of preparation and support during their pre-service year. As expected beginning teachers believe that practice teaching and experience with students and curricula with advice from associate teachers is critical to initial success in the classroom.

Instructional contexts describe specific learnings, knowledge and skills believed to be important to be a successful beginning teacher. Differences across groupings and items were minimal and reflect a general set of preferences. Ranking is of little significance other than to understand that they reflect stated priorities and decisions of forced choice in terms of responses instead of one response being preferred over another. Knowledge and use of instructional strategies, planning and organizational skills, content regarding special education and school law as well as classroom management and assessment practices are perceived as important tools in the successful application of practice teaching responsibilities and first year teaching experiences. This may not be surprising since the faculty curriculum stresses these items in much the same way.

Other professional responsibilities and services that are perceived to contribute to the success of a beginning teacher and are important to know or rely on, were, in order, faculty of education professors, reporting to parents, handling discipline issues, individual stress, communication with parents and contact with superintendents.

Candidates were invited to rank items by writing their own list of important need to know professional competencies. Combined ranking for both surveys and across divisions revealed that assessment and evaluation emerged as the highest need. Classroom management issues and information about meeting with parents/interviews were consistently ranked high. Lesson planning ranked fifth on the pre-survey but decreased in importance on the post-survey. This is understandable since experience with lesson planning and instruction decreases anxiety about this facet of teacher skills. In contrast, special education issues that originally were ranked sixth in the pre-survey moved up to fourth place on the post-survey. This may be attributed to pre-service students' exposure to working with special needs students within the classroom context. Access to resources appeared to maintain a consistent ranking of seventh on both the pre- and post-surveys. What is very interesting to note, however, is the low ranking on both the pre- and post-survey with regard to the issues related to motivating students and instructional strategies. These two areas are an integral part of many of the higher ranked topics, yet on their own they are 
seen as less important as indicated by the ranking they were given by the student teachers both on the pre and post-survey. One explanation for this is that perhaps most of the items were perceived as important however the task of selecting one over another, as revealed by the very slight changes in means, suggests that little significance should be attributed to minor differences in rank for those items that are ranked closely together.

\section{Summary}

Clearly pre-service teachers who responded to the pre- and post-test components of this research have a consistent idea about what is important to them in terms of preparation for teaching in their early years. These can be categorized in terms of support from experienced professionals and peers, program curriculum and instructional strategies, and related responsibilities and practices. The results are similar to other studies that show that beginning teachers value the input of professional practice and particularly their associations with professionals. They view support from their peers as crucial. As well, they recognize the need to master the skills associated with delivery of instruction and the roles and responsibilities associated with being a teacher. It is interesting that assessment and evaluation, reporting to parents and classroom management issues were significantly lower on the priority scale than what might have been expected on the pre and post survey items. Yet when asked need to know professional competencies these same items ranked higher. Similarly meeting learner needs was also prioritized as less important than what might have been expected on the surveys but in post survey free response the items were prioritized much higher. We surmise this is due to dissonance between what is generally unknown by novice teachers prior to field based experience and subsequent reflection on what is or might be important as the realization that soon they will assume responsibility for a classroom as a certified teacher becomes a closer reality.

What is important, is that beginning teachers expect to be involved with veteran teachers and receive support from school principals in their pre-service and induction years. The message for school boards is to ensure that programs are available for beginning teachers and that assurances are given to pre-service candidates that these types of opportunities do exist and will be made available. It is also important for Faculty of Education professors to understand the importance pre-service candidates ascribe to professional practice and the practice teaching opportunities in schools provided by the practicum. Clearly the counselling group experience and the integrated practice component provided by the Brock Faculty of Education Pre-service program supports the expressed views of candidates in this regard.

\section{Recommendations}

Based on the results of this study, the following recommendations appear appropriate:

- School boards should work with faculties of education to advise them of the types of programs that are available and how and when novice teachers will be involved.

- School Bcards should provide professional development workshops to novice teachers with respect to employment opportunities and internship support they provide during the first two years of teaching.
- Professors of education should become aware of and be sensitive to the needs of beginning teachers to understand and relate to the professional world to which they aspire, by learning about the culture and practices of school boards most likely to employ graduates.

- A research study should be implemented to determine the types of induction/ internship experiences offered by school boards and the extent to which they provide follow-up to the professional training experienced at faculties of education. The qualitative phase of this research will provide data in this respect.

- Research should begin to determine how faculty of education courses and school board induction practices could be linked.

- Dialogue should begin to determine how faculty of education professors might become involved with school boards in the development and delivery of induction/internship practices.

- School boards and faculties of education should work together to develop accredited professional learning programs (PLP) that can be incorporated into induction and internship experiences offered to novice teachers.

- Given the significant differences obtained on several of the indices it would be appropriate to determine why these exist and to what extent they have influence on practice and career paths of males and females as they proceed from novices to experienced professionals.

- This study should be replicated on a wider scale employing a broader range of participants from a variety of faculties of ed- 
ucation at the provincial, national and perhaps global levels.

Finally, it is only through the accumulation of small specific facts that knowledge can be increased. This study consists of two phases. Phase one involved development of a survey instrument, pilot testing, and administration of the questionnaire in pre-practice and post-practice teaching time frames. The second phase will involve contacting candidates who indicated a willingness to partici-

Table 1

\begin{tabular}{|l|c|c|c|c|c|}
\hline \multicolumn{6}{|c|}{ Descriptive Means for Professional Coaching and Advice by Veterans } \\
\hline \multicolumn{1}{|c|}{ Responses } & $\mathrm{N}$ & Pre mean & $\mathrm{N}$ & Post mean & Rank \\
\hline Experienced teachers & 499 & 4.50 & 407 & 4.50 & 2 \\
Teachers at same grade level & 498 & 4.46 & 407 & $4.61 \Delta$ & 1 \\
Peer teachers (same division) & 487 & 4.23 & 217 & $4.29 \Delta$ & 3 \\
Using the curricula & 497 & 4.14 & 407 & $4.21 \Delta$ & 6 \\
Principal & 500 & 4.08 & 407 & $4.23 \Delta$ & 4 \\
Enhanced teaching practice & 483 & 4.07 & 396 & $4.19 \Delta$ & 9 \\
Teachers in same division & 498 & 4.06 & 393 & $4.22 \Delta$ & 5 \\
Resource teachers & 499 & 4.05 & 406 & $4.19 \Delta$ & 7 \\
Vice principal & 496 & 4.04 & 404 & $4.18 \Delta$ & 8 \\
& & & & & \\
\hline
\end{tabular}

Table 2

\begin{tabular}{|l|c|c|c|c|c|}
\hline \multicolumn{6}{|c|}{ Descriptive Means for Curriculum and Instructional Skills } \\
\hline \multicolumn{1}{|c|}{ Responses } & $\mathrm{N}$ & Pre means & $\mathrm{N}$ & Post Means & Rank \\
\hline Providing emotional support & 484 & 3.90 & 396 & $3.94 \Delta$ & 2 \\
Formal induction program & 479 & 3.88 & 398 & $3.97 \Delta$ & 1 \\
Improving collegiality & 480 & 3.81 & 395 & 3.81 & 5 \\
Meeting learner needs & 495 & 3.78 & 406 & $3.63 \Delta \Delta$ & 7 \\
Classroom motivation & 496 & 3.78 & 407 & 3.78 & 6 \\
Legal and ethical issues & 490 & 3.78 & 407 & $3.87 \Delta$ & 3 \\
Special Education & 482 & 3.72 & 405 & $3.84 \Delta$ & 4 \\
Classroom management & 498 & 3.70 & 407 & $3.78 \Delta$ & 6 \\
Assessment & 496 & 3.69 & 405 & $3.25 \Delta \Delta$ & 8 \\
\hline
\end{tabular}

Table 3

\begin{tabular}{|l|c|c|c|c|c|}
\hline \multicolumn{7}{|c|}{ Descriptive Means for Professional Responsibilities } \\
\hline \multicolumn{1}{|c|}{ Responses } & $\mathrm{N}$ & Pre mean & $\mathrm{N}$ & Post Means & Rank \\
\hline Professors at F.O.E. & 491 & 3.53 & 403 & $3.13 \Delta \Delta$ & 2 \\
Reporting to parents & 491 & 3.41 & 402 & $2.95 \Delta \Delta$ & 4 \\
Handling discipline issues & 494 & 3.30 & 406 & $3.48 \Delta$ & 1 \\
Stress & 493 & 3.15 & 407 & $2.97 \Delta \Delta$ & 3 \\
Communication with parents & 495 & 3.06 & 407 & $2.82 \Delta \Delta$ & 5 \\
Superintendents & 498 & 2.73 & 404 & $2.53 \Delta \Delta$ & 6 \\
\hline
\end{tabular}




\section{Selected References}

Clifford, F. (1991). A policy perspective on teacher induction. Orbit, February 7-8.

Chodzinski, R.T. (2002). Searching for advanced skills teachers and expert advice to beginners: Best practices. Paper presented at the American Association of Behavioral and Social Sciences. Las Vegas Nevada, February 11-14.

Chodzinski, R.T., (1994). Goals of beginning teachers, Brock Education, 3 (3), 11-16.

Chodzinski, R.T., (1991). Alliance: A model for internship in teacher education at the intermediate and senior divisions, Brock Education, 1(1) Winter.

Cowieson, L. (1995). An apology for exemplary practice in public education in Ontario, Orbit, 26 (4), 2.

Cobb, V.L. Darling-Hammond, L.\& Murangi (1995). Teacher prepara- tion and professional development in APEC members. An overview of policy and practice. In L. Darling-Hammond \& V.L. Cobb, (Eds.), Teacher preparation and professional development in APEC members: A comparative study (pp-1-16). Washington, D.C.: U.S. Department of Education. (Eric Document Reproduction services No.ED383683).

Cole, A. (1991). Induction programs in Ontario schools. Orbit, February, 2-4.

Darling-Hammond, L. (1999). Reshaping teaching policy, preparation and practice. Influences of the National Board for Professional Teaching Standards. Washington, D.C.: American Association of Colleges for Teacher Education. (ERIC Document Reproduction Service No. ED432 570).

Kagan, D. M. (1992). Professional growth among pre-service and be- ginning teachers. Review of Educational Research, 62, (2), 129-169.

Michael E. Manley-Casimir (2001). "Anchors of Stability Amidst the Tides of Change? The Challenge to Teacher Preparation" Education Canada v. 41, \#2, Summer, pp. 4-7, \& p.38.

Matier, M. (2002). Induction Practices: A director of education's perspective. Teaching and Learning, A Journal of the Brock Faculty of Education Consortium.1 (1) 4.

National Commission on Teaching and America's Future. (1996). What matters most: Teaching for America's future. New York: Author.

Stombus, G. and Chodzinski, R.T. (1998). Alternative induction and internship models for teacher preparation. Presented at ISTE, Canterbury England, April.

\section{Contributors}

Lorenzo Cherubini M.Ed. is a vice principal with Halton Catholic District School Board. A former student of Brock University, he is currently enrolled in a Ph.D. program with the University of Southern Queensland, Toowoomba, Australia. His research focus is leadership through innovative induction and mentorship strategies.

Raymond Chodzinski Ph.D. is the Associate Dean of the Faculty of Education, Brock University, Hamilton Campus. His research interests include students at risk, violence in schools and communities, therapeutic storytelling and advancement of best practices in education and counselling. He is highly regarded as a motivational speaker and conference presenter.

Barry Finlay is Superintendent, Halton District School Board; Gail Phillips is Curriculum Coordinator (French) and leader of the Partners in the Classroom Program; Alison Cail is a teacher with Grove Public School and Lindsay Clarke is a teacher at Foster Public school. This team is committed to mentoring and induction through partnerships that stress a welcoming attitude and a desire to collaborate toward effective classroom instruction and successful student learning.

Joanne Graham Ed.D. is an Assistant Professor with the Faculty of Education. She has extensive experience as a teacher and coordinator with various school jurisdictions. Joanne is Coordinator of the Hamilton Campus, Pre-service Program. Her research focus is mathematics education and teacher induction. Her innovative approach to mathematics instruction has received international attention.
Kris Kirkwood Ed.D. is an Associate Professor in the Faculty of Education, Brock University. His career includes a variety of teaching and supervisory positions as well as extensive international consulting. His research interests include survey research and measurement and evaluation. He is highly regarded as a consultant in these areas.

Michael Manley-Casimir Ph.D. is the Dean of the Faculty of Education.His research focuses on ethics and justice issues in education as well as legal concerns for teachers in practice. Dr. Manley-Casimir is an accomplished academic author and an etymology enthusiast. He is currently Chair of the Association of Ontario Deans of Education.

Merv Matier M.Ed. is the Director of Education for the Hamilton-Wentworth District School Board. His vast career experience includes appointments as a teacher and supervisory officer in Ireland, West Germany and with the Toronto Board of Education. He is committed to the philosophy that all students have the potential to be successful learners and that it is the responsibility of the school institution to facilitate such potential.

Michael Simpson M.Ed. is the principal of Eastdale Secondary School in Welland. He is interested in encouraging effective career pathways through collaborative ventures and partnerships with Faculties and schools. 